\title{
Compositional, Functional and Sensory Characteristics of Selected Mexican Cheeses
}

\author{
Irma Caro $^{1}$, Sergio Soto ${ }^{2}$, Lucía Fuentes ${ }^{1,3}$, Néstor Gutiérrez-Méndez ${ }^{4}$, Briselda García-Islas ${ }^{2}$, \\ Karol E. Monroy-Gayosso ${ }^{2}$, Javier Mateo ${ }^{1^{*}}$ \\ ${ }^{1}$ Departamento de Higiene y Tecnología de los Alimentos, Universidad de León, León, Spain; ${ }^{2}$ Centro de Investigación en Ciencia y \\ Tecnología de los Alimentos, Instituto de Ciencias Agropecuarias, Universidad Autónoma del Estado de Hidalgo, Tulancingo, Mex- \\ ico; ${ }^{3}$ Instituto Tecnológico Superior del Oriente del Estado de Hidalgo, Apan, Mexico; ${ }^{4}$ Facultad de Ciencias Químicas, Universidad \\ Autónoma de Chihuahua, Chihuahua, Mexico. \\ Email: jmato@unileon.es
}

Received October 29 $9^{\text {th }}, 2013$; revised November $29^{\text {th }}$, 2013; accepted December $8^{\text {th }}, 2013$

Copyright (C) 2014 Irma Caro et al. This is an open access article distributed under the Creative Commons Attribution License, which permits unrestricted use, distribution, and reproduction in any medium, provided the original work is properly cited. In accordance of the Creative Commons Attribution License all Copyrights (C) 2014 are reserved for SCIRP and the owner of the intellectual property Irma Caro et al. All Copyright (C 2014 are guarded by law and by SCIRP as a guardian.

\section{ABSTRACT}

The aim of this study was to describe the compositional, functional and sensory properties of six traditional Mexican cheeses: Panela, Oaxaca, Manchego, Manchego Botanero, Tenate, and Morral. A total of 50 cheeses were analysed. Relevant compositional parameters including $\mathrm{pH}, \mathrm{a}_{\mathrm{w}}$, proximate composition, $\mathrm{NaCl}$, sugars, lactic and acetic acids, mineral contents, free-amino acid nitrogen, fat acid degree value and total fatty acids were determined. In addition, colour and texture profile analyses of unmelted cheeses and their meltability were investigated. Furthermore, other 30 cheeses were used for a descriptive sensory analysis. Properties of cheeses were described, compared between each cheese, and related to their respective making processes.

\section{KEYWORDS}

\section{Cheese Properties; Oaxaca; Panela; Manchego; Botanero; Morral; Ethnic Food; Tenate; Traditional Cheese}

\section{Introduction}

There are a considerable variety of local cheeses in Mexico, with most of them evolving from traditional farmhouse methods. Six of the typical cheeses from Central Mexico are Panela, Oaxaca, Mexican-Manchego, Manchego-Botanero, Tenate, and Morral. These are all made from cows' milk and are usually marketed and consumed unripened or shortly ripened. Hnosko et al. [1] have described the sensorial characteristics of some of those cheeses. In their study, the increasing popularity of Latin American cheeses in USA has been remarked.

Scientific international literature on the subject of Mexican cheeses has been focused on different aspects. Several studies have been conducted on food safety [2-4] or isolation and characterization of microflora [5-7]. Furthermore, an increasing number of studies dealing with the chemical and functional properties of Mexican chees-

*Corresponding author. es, i.e., Chichuahua, Fresco, Panela, Asadero and Oaxaca, have been recently published [8-15]. However, to our better knowledge, there is no information on the chemical, functional and/or sensory characteristics of most of the cheeses considered in the present study.

Therefore, the aim of this study was to investigate the chemical composition and functional and sensory characteristics of the six above-mentioned cheese varieties. This information would be useful not only for the cheesemaking industry involving those cheeses production, but also for the protection and preservation of cheese-making traditions.

\section{Materials and Methods}

\subsection{Sampling}

For the chemical and functional analyses, 50 cheeses (9 Panela, 10 Oaxaca, 9 Botanero, 9 Mexican Manchego, 6 Tenate and 7 Morral) were sampled from 17 regional 
dairy plants in Central Mexico, just prior to being sent to retail markets. Once sampled, cheeses were transported to the laboratory and were stored in their original packages for 4 days at $5^{\circ} \mathrm{C}$ in an attempt to simulate the conditions at retail stores. After this period, $\mathrm{pH}$, colour, texture, and meltability analyses were carried out. Then, 250 $\mathrm{g}$ of each sample were homogenized and kept frozen at $-40^{\circ} \mathrm{C}$ until further chemical analysis. Moreover, 5 additional cheeses from each type were sampled for the sensory analysis. These cheeses were not stored after sampling, i.e., they were analyzed on the next day of sampling.

Key points of the making process of the cheeses sampled, according to the cheese producers, are shown in Table 1, and Figure 1 shows photographs of each of the cheeses studied.

\subsection{Chemical Analyses}

The $\mathrm{pH}$ of cheeses was measured after homogenising the sample with distilled water $(1: 5, \mathrm{w} / \mathrm{v})$. Water activity $\left(\mathrm{a}_{\mathrm{w}}\right)$ was determined at $25^{\circ} \mathrm{C}$ using an Aqualab CX-2 hygrometer (Decagon Devices, Inc. Pullman, WA, USA). Moisture, fat, protein, and ash contents were determined in triplicate (Official Methods no. 926.08, 933.05, 920.123 and 935.42, respectively) [16]. Lactose, galactose, $\mathrm{NaCl}$, lactic and acetic acids, and free amino acid nitrogen $\left(\alpha-\mathrm{NH}_{2}-\mathrm{N}\right)$ were first extracted from cheese samples with $4.5 \mathrm{mM} \mathrm{H}_{2} \mathrm{SO}_{4}$ [17]. Lactic and acetic acids were analyzed according to the method described by González de Llano et al. [18]. Extracts were filtered through $0.45-\mu \mathrm{m}$ filters, and $30 \mu \mathrm{L}$ of filtrate were injected into the chromatograph. The analysis was performed using a Waters 2690 separation module (Waters Corporation, Milford, MA, USA) equipped with an Aminex HPX-87H ion exchange column (Bio-Rad Laboratories, Inc., Hercules, CA, USA), protected by a cation $\mathrm{H}^{+}$ Microguard cartridge (Bio-Rad Laboratories, Inc.), and maintained at $65^{\circ} \mathrm{C}$. Detection was carried out at $210 \mathrm{~nm}$ with a Waters 996 photodiode array detector (Waters Corporation). Elution was performed with $3 \mathrm{mM} \mathrm{H}_{2} \mathrm{SO}_{4}$ at an initial flow of $0.5 \mathrm{~mL} \cdot \mathrm{min}^{-1}$ for $30 \mathrm{~min}$, after which it was increased to $0.8 \mathrm{~mL} \cdot \mathrm{min}^{-1}$ up to $40 \mathrm{~min}$. Sugars and $\mathrm{NaCl}$ were analyzed using the same methodology to the one used for lactic and acetic acid, except for that the column temperature was $60^{\circ} \mathrm{C}$, detection was carried out using a Waters 410 differential refractometer (Waters Corporation) and the eluent was $5 \mathrm{mM} \mathrm{H}_{2} \mathrm{SO}_{4}$ at a constant flow of $0.6 \mathrm{~mL} \cdot \mathrm{min}^{-1}$. Finally, total free $\alpha-\mathrm{NH}_{2}-\mathrm{N}$ groups in that extract were analyzed in duplicate according to the method described by Rosen [19].

For mineral content determination, duplicate aliquots of approximately $1 \mathrm{~g}( \pm 0.01)$ of each of the homogenized cheese samples were accurately weighed and digested with $10 \mathrm{~mL}$ of concentrated $\mathrm{HNO}_{3}$ in tightly closed screw
Table 1. Key points in the cheese making processes.

\begin{tabular}{|c|c|}
\hline Panela & $\begin{array}{l}\text { Pasteurized milk; rennet coagulation. } \\
\text { Curd grain at cutting: } 1-2 \mathrm{~cm}^{3} \text {. } \\
\text { Curd time in vat before draining: } 30 \mathrm{~min} \text {. } \\
\text { Salting in vat by adding dry salt. } \\
\text { Moulding. }\end{array}$ \\
\hline Oахаса & $\begin{array}{l}\text { Raw or pasteurized milk; mixed coagulation. } \\
\text { Curd grain at cutting: } 1 \mathrm{~cm}^{3} \text {. } \\
\text { Final pH of curd in the vat: } 5.2-5.4 \text {. } \\
\text { Kneading and stretching of curd (pasta filata) in hot } \\
\text { water (c.a., } 72^{\circ} \mathrm{C} \text { ). } \\
\text { Forming of long thin strips of curd. } \\
\text { Cooling of strips in chilled water. } \\
\text { Salting of strips by adding dry salt } \\
\text { Cutting of strings into segments. } \\
\text { Wounding of segments into balls. }\end{array}$ \\
\hline Manchego & $\begin{array}{l}\text { Pasteurized milk; mixed coagulation. } \\
\text { Curd grain at cutting: } 2-3 \mathrm{~mm}^{3} \text {. } \\
\text { Final pH of curd in the vat, } 6.2 \text {. } \\
\text { Moulded and pressed for } 6-12 \text { hours. } \\
\text { Salting by adding salt on surface. } \\
\text { Drying for } 1 \text { - } 3 \text { days at } 10^{\circ} \mathrm{C} \text {. }\end{array}$ \\
\hline Botanero & $\begin{array}{l}\text { Similar to Manchego. } \\
\text { Final pH of curd in the vat: } 5.4 \text {. } \\
\text { Herbs and Capsicum fruits, and common salt are } \\
\text { added to the curd grains before moulding. }\end{array}$ \\
\hline Tenate & $\begin{array}{l}\text { Raw milk; mixed coagulation. } \\
\text { Curd grain at cutting: } 2-3 \mathrm{~mm}^{3} \text {. } \\
\text { Final pH of curd in the vat: } 6.0 \text {. } \\
\text { Draining of curd into 5-kg capacity cloth bags for } 24 \\
\text { hours at room temperature. } \\
\text { Milling of curd (hand-broken) into small pieces and } \\
\text { salting dry salt. } \\
\text { Moulding in palm baskets, the curd is covered on the } \\
\text { upper side with cloth. } \\
\text { Slightly pressed. } \\
\text { Ripening at } 10^{\circ} \mathrm{C} \text { for one week. }\end{array}$ \\
\hline Morral & $\begin{array}{l}\text { Pasteurized milk; mixed coagulation. } \\
\text { Curd grain at cutting: } 2 \mathrm{~mm}^{3} \text {. } \\
\text { Salting in the vat with a part of the whey. } \\
\text { Final pH of curd in the vat: } 5.4-5.6 \text {. } \\
\text { Moulding and draining of curd in a cloth basket called } \\
\text { "morral". } \\
\text { Pressed. }\end{array}$ \\
\hline
\end{tabular}

cap glass tubes for $18 \mathrm{~h}$ at room temperature and then for a further $4 \mathrm{~h}$ at $90^{\circ} \mathrm{C}$. Afterwards, mineral content was determined by inductively coupled plasma atomic emission spectroscopy (ICP-AES) according to the methodology described by Osorio et al. [20].

Fat extraction was carried out by homogenizing $20 \mathrm{~g}$ of sample with $100 \mathrm{~mL}$ of chloroform and filtering. Twenty $\mathrm{ml}$ of water were then added to the filtrate and the mixture was shaken and decanted. The chloroform phase was then collected, $1 \mathrm{~g}$ of $\mathrm{Na}_{2} \mathrm{SO}_{4}$ was added, and the mixture was shaken and filtered. The determination of the acid degree value (ADV) of fat was done in duplicate by titrating $10 \mathrm{~mL}$ of lipid extract dissolved in 20 $\mathrm{mL}$ of ethanol/diethyl-ether $(1: 1, \mathrm{v} / \mathrm{v})$ with an ethanolic 


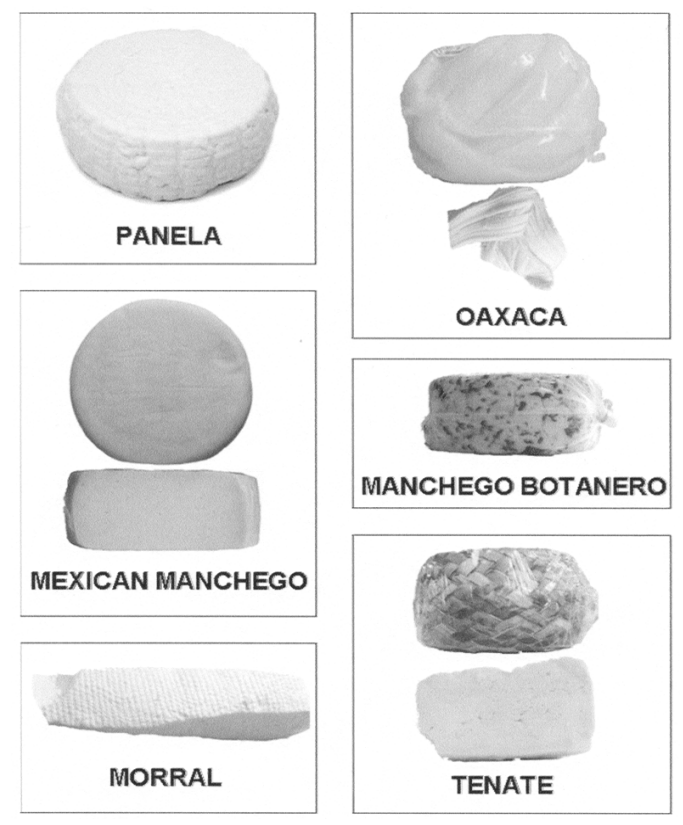

Figure 1. Photographs with the cheeses sampled.

$0.02 \mathrm{M} \mathrm{KOH}$ solution, using phenolphthalein as indicator. To determine total fatty acid (FA) composition of cheeses, $0.250 \mathrm{~g}$ of lipids from each sample were lyophilized and the transesterification-in-situ technique described by [21] was followed. Analysis of FA was performed according to Osorio et al. [22].

\subsection{Functional Properties}

The $L^{*}, a^{*}$, and $b^{*}$ colour values of cheese samples were measured in triplicate at room temperature on the cheese surface using a Minolta Colorimeter CR-300 (Konica Minolta, Osaka, Japan). The measurement conditions were: D65 illuminant, $10^{\circ}$ observed angle, SCI mode, 11 $\mathrm{mm}$ aperture for illumination, and $8 \mathrm{~mm}$ aperture for measurement.

Samples for texture profile analysis (TPA) were obtained from the core of the whole cheese blocks, discarding $0.5 \mathrm{~cm}$ of the outer layer, except for Oaxaca cheese, where that layer was not removed. A total of four 20-mm-sided cheese cubes were placed in an airtight plastic bag, sealed to prevent dehydration, and held in an incubator at $8^{\circ} \mathrm{C}$ overnight before measurement. A twobite penetration test was performed using the Texture Analyser (TAHDi; Texture Technologies Corporation, Scarsdale, NY, USA). The instrument operated with a 50$\mathrm{kg}$ load cell and a 100-mm-diameter disk-shaped probe, moving at a crosshead speed of $1 \mathrm{~mm} \cdot \mathrm{s}^{-1}$ for a penetration distance of $10 \mathrm{~mm}$. Hardness, adhesiveness, springiness, and cohesiveness were evaluated [23]. In addition, melt time and flowability were determined in triplicate according to the method described by Guinee et al. [24]. Flowability was expressed as the percentage increase in diameter of a cheese disc upon heating at $280^{\circ} \mathrm{C}$ for 4 min.

\subsection{Sensory Analysis}

A quantitative descriptive sensory analysis of cheeses was carried out by a group of 12 assessors. Assessors (4 men and 8 women, with a mean age of 25 years old) were staff and students of the Instituto de Ciencias Agropecuarias (ICAP), Universidad Autónoma del Estado de Hidalgo (Tulancingo, Mexico). Assesors were trained in ten twenty-minute sessions. During training, relevant flavour and and texture characteristics of cheeses were explained and discussed $[25,26]$. Then, two Mexican cheeses of each type, which were purchased from the market, were tasted. Afterwards, assessors selected a reduced number of characteristics that were considered as most appropriate for the flavour and texture description of the Mexican cheeses. Selected characteristics were defined and discussed; moreover, reference standards for those characteristics were prepared and presented to the assessors. The proposed characteristics (into brackets the reference used) were: sweetness, acidness, saltines, bitterness and pungent (1.5 $\mathrm{g}$ of fructose, $3 \mathrm{~g}$ of citric acid, $7 \mathrm{~g}$ of NaCl, $1 \mathrm{~g}$ of cafein and $2 \mathrm{~g}$ of "chile jalapeño"-capsicum fruit per $100 \mathrm{~g}$ of non-salted ricotta, respectively); cooked milk (UHT milk); sour (acidified milk by an homofermentative culture); buttery (10 g of butter dispersed in $100 \mathrm{ml}$ of milk); intensity and persistence ( $2 \mathrm{ml}$ of Cheddar cheese flavour in $100 \mathrm{ml}$ of milk); moistness (watermelon); crumblines (cooked egg white as no crumbly and a muffling as high crumbly standard); and creaminess (spreadable processed cheese). Finally, the cheeses purchased for training were tasted and ranked according to the intensity of the characteristic proposed.

The sensory analysis was carried out in one session for each cheese type (six sessions in total, five samples by session), at the ICAP's tasting room, in individual partitioned-off booths under soft white lighting and at $20^{\circ} \mathrm{C}$. Five $1.5-\mathrm{cm}$ cubes of each sample were presented in white plastic dishes, coded with randomly chosen 3-digit numbers. A small cup of still mineral water and salt-free bread crackers were given to the assesors to cleanse their palate between samples.

Assessors were asked to evaluate the selected flavour and texture characteristics on a nine-point linear scale, where 1 represented the absence or very low intensity of a specific flavour or texture descriptor and 9 a very high intensity (referred to the reference standard). Assessors were allowed to swallow the samples if so desired.

\subsection{Statistical Analysis}

One-way ANOVA analysis was used in order to detect significant differences between cheese types. Means of 
variables for each pair of cheeses were compared using the Tukey statistical test (Statistica, release 6.0; Statsoft inc., Tulsa, OK, USA).

\section{Results and Discussion}

\subsection{Chemical Composition}

The values of $\mathrm{pH}, \mathrm{a}_{\mathrm{w}}$, and the other chemical parameters of cheeses are shown in Table 2. Amongst the cheeses studied, Panela appeared to be the most different cheese. This finding can be explained by three main reasons: 1 ) The frequent use in Panela cheese making of skim milk or casein-fortified milk, which would be responsible for a lower fat-in-dry matter; 2) The differentiated coagulation process in Panela-cheese making (rennet coagulation), which would account for the $\mathrm{pH}$-related differences; 3)
The larger size of the curd grains and the shorter time in the vat after cutting in Panela cheese making, which would result in a higher moisture content.

The $\mathrm{pH}$ of recently produced Panela should be similar to the $\mathrm{pH}$ of fresh milk (6.7 - 6.8). However, bacterial growth in milk and the subsequent acidification of cheese during distribution and storage could account for the lower $\mathrm{pH}$ of cheeses (6.1). The composition of Panela cheese was comparable to that obtained for other soft fresh rennet-coagulated cheeses such as the Spanish Burgos cheese [27] or a Belgium soft cheese variety [28]. Composition of Panela was also similar to those of other Latin American fresh cheeses such as the Mexican Fresco $[6,29]$ or the Brazilian Minas Frescal [30], although $\mathrm{pH}$ and moisture content were slightly higher in the Panela cheese.

Table 2. $\mathbf{p H}, \mathbf{a}_{\mathrm{w}}$, concentrations and ratios of six Mexican cheeses; mean values (standard deviations).

\begin{tabular}{|c|c|c|c|c|c|c|}
\hline & Panela (n = 9) & Oaxaca $(\mathrm{n}=10)$ & Manchego ( $\mathrm{n}=9$ ) & Botanero $(n=9)$ & Tenate $(\mathrm{n}=6)$ & Morral $(n=7)$ \\
\hline $\mathrm{pH}$ & $6.12(0.41)^{\mathrm{a}}$ & $5.02(0.21)^{\mathrm{b}}$ & $5.30(0.21)^{\mathrm{b}}$ & $5.40(0.43)^{\mathrm{b}}$ & $5.34(0.16)^{b}$ & $5.31(0.11)^{\mathrm{b}}$ \\
\hline$a_{w}$ & $0.988(0.004)^{\mathrm{a}}$ & $0.973(0.006)^{\mathrm{b}}$ & $0.968(0.007)^{\mathrm{b}}$ & $0.968(0.009)^{\mathrm{b}}$ & $0.963(0.007)^{\mathrm{b}}$ & $0.971(0.009)^{\mathrm{b}}$ \\
\hline Moisture (\%) & $54.2(5.2)^{\mathrm{a}}$ & $50.8(2.2)^{\mathrm{ab}}$ & $42.1(3.4)^{\mathrm{cd}}$ & $46.3(3.5)^{\mathrm{bc}}$ & $40.3(2.9)^{\mathrm{d}}$ & $44.3(3.6)^{\mathrm{cd}}$ \\
\hline Fat (\%) & $18.8(3.36)^{\mathrm{d}}$ & $22.4(2.52)^{\mathrm{d}}$ & $28.4(3.51)^{\mathrm{ab}}$ & $25.9(3.04)^{\mathrm{bc}}$ & $31.8(3.57)^{\mathrm{a}}$ & $29.0(0.70)^{\mathrm{ab}}$ \\
\hline Protein (\%) & $18.4(2.16)^{\mathrm{c}}$ & $21.4(1.40)^{\mathrm{b}}$ & $26.0(1.59)^{\mathrm{a}}$ & $22.2(1.83)^{\mathrm{b}}$ & $22.4(1.01)^{\mathrm{b}}$ & $22.1(2.77)^{\mathrm{b}}$ \\
\hline Lactose (\%) & $2.23(0.75)^{\mathrm{a}}$ & $0.15(0.16)^{b}$ & $0.23(0.22)^{\mathrm{b}}$ & $0.13(0.13)^{\mathrm{b}}$ & $0.15(0.15)^{\mathrm{b}}$ & $0.20(0.21)^{\mathrm{b}}$ \\
\hline Galactose (\%) & $0.19(0.35)^{\mathrm{a}}$ & $0.19(0.27)^{\mathrm{a}}$ & $0.62(0.42)^{\mathrm{a}}$ & $0.23(0.28)^{\mathrm{a}}$ & $0.16(0.25)^{\mathrm{a}}$ & $0.27(0.24)^{\mathrm{a}}$ \\
\hline Ash (\%) & $2.57(0.29)^{\mathrm{c}}$ & $3.50(0.40)^{\mathrm{ab}}$ & $3.39(0.44)^{\mathrm{ab}}$ & $3.76(0.67)^{\mathrm{a}}$ & $3.95(0.50)^{\mathrm{a}}$ & $3.02(0.26)^{\mathrm{bc}}$ \\
\hline $\mathrm{NaCl}(\%)$ & $1.41(0.38)^{\mathrm{b}}$ & $1.61(0.69)^{\mathrm{ab}}$ & $1.69(0.81)^{\mathrm{ab}}$ & $1.79(0.64)^{\mathrm{ab}}$ & $2.46(0.80)^{\mathrm{a}}$ & $1.16(0.48)^{\mathrm{b}}$ \\
\hline Fat-in-DM (\%) & $40.0(3.2)^{\mathrm{c}}$ & $45.6(4.9)^{\mathrm{bc}}$ & $48.5(4.3)^{\mathrm{ab}}$ & $48.3(4.1)^{\mathrm{ab}}$ & $53.2(5.4)^{\mathrm{a}}$ & $52.3(2.0)^{\mathrm{ab}}$ \\
\hline Protein-in-DM (\%) & $39.5(4.0)^{\mathrm{ab}}$ & $43.5(2.8)^{\mathrm{a}}$ & $44.6(4.8)^{\mathrm{a}}$ & $41.5(3.9)^{\mathrm{ab}}$ & $37.6(2.5)^{b}$ & $39.3(3.1)^{\mathrm{ab}}$ \\
\hline MNFS (\%) & $65.4(3.9)^{\mathrm{a}}$ & $65.6(2.8)^{\mathrm{a}}$ & $58.8(2.9)^{\mathrm{b}}$ & $62.5(3.5)^{\mathrm{ab}}$ & $59.1(4.0)^{\mathrm{b}}$ & $65.0(3.0)^{\mathrm{a}}$ \\
\hline $\mathrm{NaCl} /$ moisture ratio & $0.024(0.005)^{\mathrm{b}}$ & $0.032(0.010)^{\mathrm{b}}$ & $0.041(0.020)^{\mathrm{ab}}$ & $0.039(0.014)^{\mathrm{ab}}$ & $0.062(0.024)^{\mathrm{a}}$ & $0.027(0.013)^{\mathrm{b}}$ \\
\hline Moisture/protein ratio & $3.00(0.54)^{\mathrm{a}}$ & $2.39(0.22)^{b}$ & $1.62(0.15)^{d}$ & $2.10(0.28)^{\mathrm{bc}}$ & $1.80(0.15)^{\mathrm{cd}}$ & $2.02(0.39)^{\mathrm{bc}}$ \\
\hline Lactic acid (\%) & $0.53(0.24)^{\mathrm{b}}$ & $1.89(0.48)^{\mathrm{a}}$ & $2.12(0.75)^{\mathrm{a}}$ & $2.23(0.92)^{\mathrm{a}}$ & $1.73(0.50)^{\mathrm{a}}$ & $2.36(0.53)^{\mathrm{a}}$ \\
\hline Acetic acid (\%) & $0.06(0.06)^{\mathrm{ab}}$ & $0.07(0.05)^{\mathrm{ab}}$ & $0.03(0.04)^{\mathrm{b}}$ & $0.14(0.09)^{\mathrm{a}}$ & $0.16(0.08)^{\mathrm{a}}$ & $0.03(0.03)^{\mathrm{b}}$ \\
\hline$\alpha-\mathrm{NH}_{2}-\mathrm{N}$ & $0.91(0.21)^{\mathrm{a}}$ & $1.86(0.74)^{\mathrm{b}}$ & $1.45(0.54)^{\mathrm{ab}}$ & $1.50(0.46)^{\mathrm{ab}}$ & $1.43(0.20)^{\mathrm{ab}}$ & $1.43(0.50)^{\mathrm{ab}}$ \\
\hline $\mathrm{ADV}$ & $4.18(0.78)^{\mathrm{ab}}$ & $3.43(0.67)^{\mathrm{b}}$ & $5.50(1.63)^{\mathrm{a}}$ & $4.78(1.42)^{\mathrm{ab}}$ & $4.54(0.60)^{\mathrm{ab}}$ & $5.18(1.80)^{\mathrm{ab}}$ \\
\hline Ca (mg $\left.\cdot 100 \mathrm{~g}^{-1}\right)$ & $717(65)^{\mathrm{a}}$ & $581(66)^{b}$ & $769(97)^{\mathrm{a}}$ & $708(98)^{a}$ & $771(35)^{\mathrm{a}}$ & $770(95)^{\mathrm{a}}$ \\
\hline $\mathrm{Na}\left(\mathrm{mg} \cdot 100 \mathrm{~g}^{-1}\right)$ & $431(83)^{b}$ & $638(192)^{\mathrm{ab}}$ & $615(245)^{\mathrm{ab}}$ & $686(224)^{\mathrm{ab}}$ & $866(274)^{\mathrm{a}}$ & $419\left(141^{\mathrm{b}}\right.$ \\
\hline $\mathrm{P}\left(\mathrm{mg} \cdot 100 \mathrm{~g}^{-1}\right)$ & $439(31)^{\mathrm{ab}}$ & $405(29)^{b}$ & $459(38)^{\mathrm{a}}$ & $455(39)^{\mathrm{a}}$ & $481(33)^{\mathrm{a}}$ & $451(35)^{\mathrm{ab}}$ \\
\hline $\mathrm{K}\left(\mathrm{mg} \cdot 100 \mathrm{~g}^{-1}\right)$ & $121(34)^{\mathrm{a}}$ & $78(15)^{b}$ & $100(10)^{\mathrm{ab}}$ & $95(17)^{\mathrm{ab}}$ & $118(26)^{\mathrm{a}}$ & $102(12)^{\mathrm{ab}}$ \\
\hline $\operatorname{Mg}\left(\mathrm{mg} \cdot 100 \mathrm{~g}^{-1}\right)$ & $30(3)^{\mathrm{a}}$ & $22(3)^{b}$ & $30(3)^{\mathrm{a}}$ & $30(3)^{\mathrm{a}}$ & $30(2)^{\mathrm{a}}$ & $31(4)^{\mathrm{a}}$ \\
\hline
\end{tabular}

$\alpha$ - $\mathrm{NH}_{2}-\mathrm{N}$ : $\alpha$-amino acid nitrogen expressed as percentage of $\alpha-\mathrm{NH}_{2}-\mathrm{N}$ in total $\mathrm{N}$; ADV: acid degree value expressed as mmol KOH. $100 \mathrm{~g}{ }^{-1}$ fat; DM: dry matter; MNFS: moisture-in-non-fat substances; ${ }^{\text {a,b,c }}$ : means of each raw with no common letter presented significant differences by the post-hoc Tukey test $(p<0.05)$. 
The other five cheeses studied showed a considerable number of characteristics in common. Their $\mathrm{pH}$ values were all between 5.0 and 5.4. Moreover, $\mathrm{a}_{\mathrm{w}}$ ranges were within 0.96 and 0.97 , and all of them can be classified as either semi-soft or semi-hard and fatty cheeses, according to their moisture and fat content, respectively. Furthermore, when considering their $\alpha-\mathrm{NH}_{2}-\mathrm{N}$ content, little difference was found between these five cheeses. These values were also not very different from those obtained for Panela (a cheese that is not ripened at all) probably due to absent or short ripening times.

Oaxaca cheese had the lowest $\mathrm{pH}$ value. Low curd $\mathrm{pH}$ values are already achieved in the vat [12], which would promote calcium solubilisation in the whey [31]. Both the low curd $\mathrm{pH}$ and the characteristic kneading and stretching would result in an important loss of soluble $\mathrm{Ca}^{2+}$ from the curd to the whey, which was reflected in the low $\mathrm{Ca}^{2+}$ contents (Table 2). A leaching of other soluble compounds such as phosphates, $\mathrm{Mg}^{2+}, \mathrm{K}^{+}$, lactate, etc., would also be possible. The composition of Oaxaca cheese was similar to that of Asadero, another pasta-filata Mexican cheese [8,32], with the main difference between both being a $5 \%$ higher moisture content in Oaxaca cheese. There is also a similarity between the composition of Mozzarella, particularly low-moisture Mozarrella, and Oaxaca cheese [32,33].

Mexican Manchego is normally made by mixed coagulation of pasteurized milk [3]. When compared to the other Mexican cheeses in study, Mexican Manchego showed the highest protein and one of the highest fat contents. This could be the result of an intense expulsion of whey from curd by syneresis in the vat, due to the small size of curd cubes, and/or an evaporation of moisture from the cheese surface during the ripening period. Proximate composition and $\mathrm{pH}$ values of Mexican Manchego seemed to be similar to the ones reported for Chihuahua [9,32] and Monterrey cheeses [32]. Mexican Manchego composition was also similar to that of Spanish Tetilla and San Simón cheeses [27,34].

Manchego Botanero is a variety of Mexican Manchego cheese. As a main difference, in its making process, when the curd reaches a $\mathrm{pH}$ of 5.4 - 5.6, common salt and small pieces of "chiles jalapeños" (Capsicum annuum) and "epazote" (Chenopodium ambrosioides) are added to the vat and mixed with the curd. Then, the mix is moulded and pressed. The composition of Manchego Botanero cheese was quite similar to that of Mexican Manchego, but Botanero had more moisture, which in part could be due to a shorter drying time for this cheese. Significant differences $(p<0.05)$ between these cheeses were also observed for acetic acid, with Botanero having higher values.

Tenate is a semi-hard cheese, the driest, fattiest and the highest in salt content among the cheeses studied. The draining of curd (c.a., 24 h) and the one-week ripening period would be two distinctive steps in which moisture could be lost. Finally, the composition of Morral, which is a semi-soft cheese, was intermediate for most of the parameters analyzed. However, the salt content was the lowest.

Table 3 shows the mean values of the fatty acid (FA) composition for all the Mexican cheeses studied. FA contents of individual cheeses are not shown because no significant differences were found between the cheeses studied. Moreover, only FA with levels higher than $0.5 \%$ of total FA acids were shown in the table for brevity.

Oleic acid (C18:1 n-9) was the most abundant FA, followed by palmitic (C16:0), stearic (C18:0), myristic (C14:0) and linoleic acids (C18:2 n-6). The FA composition of cheese-milk fat is relevant because it may affect significantly functional parameters of cheese such as firmness and flavour [35]. FA composition of cheese fat is roughly proportional to that of the milk used in its production. Moreover, the feeding system seems to be the main factor responsible for variations in milk FA composition [36].

\subsection{Functional and Sensory Properties}

The values found for the functional properties of the studied cheeses are shown in Table 4. Cheese colour depend on milk fat colour and the content of fat itself [37]. Furthermore, changes in the amount or structure of the skim phase of cheese may also result in changes in the absorption of light [38]. Colour parameters of Panela cheese most resembled those of milk [39]. Panela cheese had the highest lightness, while Tenate showed the lowest. Taking into account the results from all cheeses, $\mathrm{L}^{*}$ values appeared to be positively correlated to moisture content. Regarding $\mathrm{a}^{*}$ and $\mathrm{b}^{*}$ coordinates, Manchego and Manchego Botanero cheeses had the highest values for $b^{*}$, while Manchego showed the highest for ${ }^{*}$. The use of colorants and vegetables as ingredients in the manufacture of these two cheeses would account for the differences with respect to the other cheeses, where no colorants neither vegetables are usually added. The addition of natural colorants to milk is a common practice for cheese and milk product manufacture, resulting in increased values of $\mathrm{a}^{*}$ and $\mathrm{b}^{*}$ [40]. Achiote seeds (Bixa orellana) and $\beta$-carotene colorants are some of the most frequently colorants used.

Colour values for short-ripened, semi-soft cheeses (in the unmelted state) from all over the world have shown a great variability. As an example, $\mathrm{L}^{*}, \mathrm{a}^{*}$, and $\mathrm{b}^{*}$ data for three cheeses found in literature were: $86,-9$ and 24 for reduced fat Mozzarella [41]; 84, -8 and 27 for Havarti [42]; and 81, -8 and 29 for Samso [43]. In this context, the $\mathrm{a}^{*}$ values found in the six Mexican cheeses, which fell between 1.1 and 3.6, presented noticeable differences 
Table 3. Fatty acid content expressed as $\%$ in weight of total fatty acids ${ }^{\&}$; mean values (standard deviation) from all the cheeses studied, $\mathbf{n}=\mathbf{5 0}$.

\begin{tabular}{|c|c|c|c|c|c|}
\hline \multicolumn{2}{|c|}{ Saturated fatty acids } & \multicolumn{2}{|c|}{ Monounsaturated fatty acids } & \multicolumn{2}{|c|}{ Polyunsaturated fatty acids } \\
\hline C8:0 & $0.83(0.12)$ & C14:1 9c & $0.85(0.16)$ & C18:2 n6 & $2.67(0.57)$ \\
\hline C10:0 & $1.89(0.25)$ & C15:1 9c & $0.07(0.03)$ & $\Sigma \mathrm{C} 18: 2$ undiff $(4)^{\#}$ & $0.83(0.22)$ \\
\hline C12:0 & $2.43(0.29)$ & C16:1 9c & $1.65(0.20)$ & C18:3 n3 & $0.71(0.16)$ \\
\hline C14:0 & $7.94(0.96)$ & $\Sigma \mathrm{C} 16: 1$ undiff (5) & $0.53(0.14)$ & $\Sigma \mathrm{CLA}(3)^{\#}$ & $0.93(0.26)$ \\
\hline$\Sigma \mathrm{C} 15: 0 \mathrm{br}(2)^{\#}$ & $1.09(0.19)$ & C18:1 9c & 26.46 (1.89) & Total & $5.92(0.67)$ \\
\hline C15:0 & $1.45(0.21)$ & $\Sigma$ C18:1 undiff (8) & $5.90(1.03)$ & & \\
\hline C16:0 & $23.38(1.85)$ & Total & $36.83(2.25)$ & & \\
\hline$\Sigma \mathrm{C} 17: 0 \mathrm{br}(2)^{\#}$ & $1.12(0.15)$ & & & & \\
\hline C17:0 & $0.93(0.11)$ & & & & \\
\hline C18:0 & $14.85(1.72)$ & & & & \\
\hline Total & $57.42(2.55)$ & & & & \\
\hline
\end{tabular}

\& Only fatty acids exceeding the concentration of $0.50 \%$ are shown for brevity in the Table. Br: branched; Undiff: undifferentiated isomers; CLA: Conjugated linoleic acid; ": Sum of several isomers (the number between brackets corresponds to the number of isomers quantified).

Table 4. Functional parameters of the Mexican cheeses; mean values (standard deviations).

\begin{tabular}{ccccccc}
\hline & Panela (n=9) & Oaxaca $(\mathrm{n}=10)$ & Manchego (n= 7) & Botanero (n=9) & Tenate $(\mathrm{n}=6)$ & Morral $(\mathrm{n}=6)$ \\
\hline$L^{*}$ & $88.3(1.4)^{\mathrm{a}}$ & $86.0(2.9)^{\mathrm{ab}}$ & $79.6(3.1)^{\mathrm{c}}$ & $82.0(4.2)^{\mathrm{bc}}$ & $76.6(2.3)^{\mathrm{c}}$ & $81.7(4.6)^{\mathrm{bc}}$ \\
$a^{*}$ & $1.1(0.7)^{\mathrm{b}}$ & $1.0(1.00)^{\mathrm{b}}$ & $3.6(1.7)^{\mathrm{a}}$ & $1.9(0.7)^{\mathrm{b}}$ & $2.1(0.8)^{\mathrm{ab}}$ & $2.3(1.2)^{\mathrm{ab}}$ \\
$b^{*}$ & $15.1(1.4)^{\mathrm{c}}$ & $19.7(2.7)^{\mathrm{b}}$ & $23.0(1.2)^{\mathrm{a}}$ & $23.1(1.6)^{\mathrm{a}}$ & $20.5(3.3)^{\mathrm{ab}}$ & $20.2(2.6)^{\mathrm{ab}}$ \\
Hardness (N) & $24.9(5.7)^{\mathrm{bc}}$ & $14.9(6.4)^{\mathrm{c}}$ & $41.7(23.1)^{\mathrm{ab}}$ & $40.0(17.0)^{\mathrm{ab}}$ & $51.1(19.5)^{\mathrm{a}}$ & $36.1(15.6)^{\mathrm{abc}}$ \\
Springiness & $0.83(0.08)^{\mathrm{a}}$ & $0.73(0.07)^{\mathrm{b}}$ & $0.85(0.05)^{\mathrm{a}}$ & $0.86(0.04)^{\mathrm{a}}$ & $0.76(0.05)^{\mathrm{ab}}$ & $0.83(0.04)^{\mathrm{a}}$ \\
Cohesiveness & $0.52(0.08)^{\mathrm{ab}}$ & $0.62(0.09)^{\mathrm{a}}$ & $0.56(0.07)^{\mathrm{ab}}$ & $0.49(0.07)^{\mathrm{b}}$ & $0.31(0.10)^{\mathrm{c}}$ & $0.55(0.13)^{\mathrm{ab}}$ \\
Adhesiveness (N mm) & $0.17(0.14)^{\mathrm{c}}$ & $0.17(0.24)^{\mathrm{c}}$ & $1.14(0.43)^{\mathrm{b}}$ & $0.65(0.46)^{\mathrm{bc}}$ & $0.71(0.38)^{\mathrm{bc}}$ & $1.99(0.46)^{\mathrm{a}}$ \\
Flowability (\%) & $\mathrm{ND}$ & $22.8(4.0)^{\mathrm{a}}$ & $13.9(3.8)^{\mathrm{b}}$ & $16.1(8.2)^{\mathrm{ab}}$ & $12.7(3.9)^{\mathrm{b}}$ & $20.0(5.2)^{\mathrm{ab}}$ \\
Melt time (s) & $\mathrm{ND}$ & $1.5(0.4)^{\mathrm{a}}$ & $2.0(0.5)^{\mathrm{a}}$ & $1.7(0.8)^{\mathrm{a}}$ & $1.8(0.7)^{\mathrm{a}}$ & $1.6(0.7)^{\mathrm{a}}$ \\
\hline
\end{tabular}

ND: not determined. ${ }^{\mathrm{a}, \mathrm{b}, \mathrm{c}}$ : means of each raw with no common letter presented significant differences by the post-hoc Tukey test $(p<0.05)$.

with respect to those reported for the above-mentioned cheeses.

Regarding TPA parameters of unmelted cheeses (Table $4)$, most cheeses presented significant differences between each other in at least one parameter $(p<0.05)$, and Tenate and Oaxaca cheeses showed the highest differences. The former had the highest hardness and lowest cohesiveness, and the latter had the lowest hardness and springiness and highest cohesiveness. TPA has been studied in different fresh or very shortly ripened cheeses such as Colby, Havarti, Mozzarella, and Fresco cheeses $[29,44,45]$. Roughly, the values observed for the Mexican cheeses in this study fell within the range of values obtained for those cheeses.
Among the studied cheeses, Oaxaca showed the highest meltability (highest flowability and shortest melt time) (Table 4), followed by Morral and Botanero, while Manchego and Tenate showed lower meltability. The flowability values of commercial low-moisture Mozzarella, determined using the same methodology as in the present study [46], was twice as high as the values obtained for Oaxaca cheese. Differences can be related to differences in the degree of proteolysis during ripening, since Mexican cheeses are unripened or shortly ripened (up to one week) and commercial Mozzarella is normally ripened for more than one week, which is considered necessary to obtain the desired melting characteristics [33].

Finally, Table 5 shows the sensory scores of the 
Table 5. Sensory scores of the Mexican cheeses; mean values (standard deviations), $\mathbf{n}=\mathbf{5}$.

\begin{tabular}{|c|c|c|c|c|c|c|}
\hline & Panela & Oaxaca & Manchego & Botanero & Tenate & Morral \\
\hline \multicolumn{7}{|c|}{ Taste and pungency } \\
\hline Sweetness & $4.0(0.8)^{\mathrm{a}}$ & $2.9(0.5)^{\mathrm{b}}$ & $2.4(0.4)^{\mathrm{b}}$ & $2.7(0.3)^{\mathrm{b}}$ & $2.6(0.7)^{\mathrm{b}}$ & $3.4(0.4)^{\mathrm{ab}}$ \\
\hline Acidness & $3.2(1.0)^{\mathrm{b}}$ & $4.9(0.6)^{\mathrm{a}}$ & $4.2(1.0)^{\mathrm{ab}}$ & $4.4(0.9)^{\mathrm{ab}}$ & $4.2(1.0)^{\mathrm{ab}}$ & $4.4(1.1)^{\mathrm{ab}}$ \\
\hline Saltiness & $3.5(1.0)$ & $3.8(0.6)$ & $3.5(0.7)$ & $3.7(0.5)$ & $4.9(1.6)$ & $3.9(0.4)$ \\
\hline Bitterness & $2.1(0.8)$ & $2.9(0.5)$ & $3.2(0.7)$ & $3.0(0.6)$ & $3.4(1.0)$ & $3.7(1.4)$ \\
\hline Pungent & $1.2(0.2)^{\mathrm{b}}$ & $1.3(0.3)^{\mathrm{b}}$ & $1.2(0.2)^{\mathrm{b}}$ & $4.3(2.1)^{\mathrm{a}}$ & $1.5(0.3)^{\mathrm{b}}$ & $1.2(0.1)^{\mathrm{b}}$ \\
\hline \multicolumn{7}{|c|}{ Flavour } \\
\hline Cooked milk & $3.7(0.5)^{\mathrm{a}}$ & $2.6(0.4)^{\mathrm{b}}$ & $2.3(0.3)^{\mathrm{b}}$ & $2.3(0.4)^{\mathrm{b}}$ & $2.7(0.8)^{\mathrm{b}}$ & $2.7(0.4)^{\mathrm{b}}$ \\
\hline Sour & $2.8(0.9)^{\mathrm{b}}$ & $3.4(0.8)^{\mathrm{ab}}$ & $3.0(0.5)^{\mathrm{b}}$ & $3.2(0.8)^{\mathrm{ab}}$ & $4.1(0.4)^{\mathrm{a}}$ & $3.7(0.3)^{\mathrm{ab}}$ \\
\hline Buttery & $1.8(0.2)^{\mathrm{b}}$ & $3.0(0.6)^{\mathrm{a}}$ & $3.2(0.6)^{\mathrm{a}}$ & $3.1(0.2)^{\mathrm{a}}$ & $3.2(0.7)^{\mathrm{a}}$ & $3.5(0.6)^{\mathrm{a}}$ \\
\hline Intensity & $2.5(0.6)^{\mathrm{b}}$ & $3.4(0.8)^{\mathrm{a}}$ & $3.9(0.7)^{\mathrm{a}}$ & $3.9(0.2)^{\mathrm{a}}$ & $4.2(0.3)^{\mathrm{a}}$ & $4.2(0.3)^{\mathrm{a}}$ \\
\hline Persistence & $2.0(0.2)^{\mathrm{b}}$ & $2.0(0.2)^{\mathrm{b}}$ & $2.5(0.2)^{\mathrm{a}}$ & $2.8(0.3)^{\mathrm{a}}$ & $1.4(0.2)^{c}$ & $3.0(0.5)^{\mathrm{a}}$ \\
\hline \multicolumn{7}{|c|}{ Texture } \\
\hline Moistness & $4.1(0.8)$ & $3.4(0.6)$ & $3.1(0.6)$ & $3.1(0.6)$ & $3.8(0.9)$ & $3.3(0.1)$ \\
\hline Crumbliness & $4.4(0.8)^{\mathrm{b}}$ & $4.4(0.8)^{\mathrm{b}}$ & $4.0(0.2)^{\mathrm{b}}$ & $5.0(0.8)^{\mathrm{ab}}$ & $6.0(1.0)^{\mathrm{a}}$ & $5.2(0.8)^{\mathrm{ab}}$ \\
\hline Creaminess & $3.0(1.0)^{\mathrm{b}}$ & $5.4(1.3)^{\mathrm{a}}$ & $4.9(1.1)^{\mathrm{a}}$ & $5.4(1.2)^{\mathrm{a}}$ & $4.0(1.2)^{\mathrm{ab}}$ & $5.7(1.4)^{\mathrm{a}}$ \\
\hline
\end{tabular}

a,b,c: means of each raw with no common letter presented significant differences by the post-hoc Tukey test $(p<0.05)$.

cheeses. Scores for flavor were in most of the cases lower than 4 (in a 9-point scale), which indicates a no-strong flavour. Acidity was the flavour characteristic showing higher scores; nevertheless, saltiness was higher than acidness in Tenate cheese. As said before for the chemical composition, Panela was the most different cheese among the cheeses studied. Futhermore, Botanero had a high score in pungency due to the presence of hot Capsicuum fruits. With regard to texture, it should be noticed the high creaminess showed by four of the cheeses studied (all except for Panela and Tenate) and the highest crumbliness of Tenate. The last could be attributed to its distinctly making process: in Tenate cheese making, after an intense draining in a cloth bag, the curd is reduced into small pieces, which are placed into basket molds, where pieces are slightly pressed.

\section{Conclusions}

The present study provides data on the chemical composition, functional and sensory properties of six Mexican cheeses. A high variation in most of the studied parameters, i.e., proximate composition, common salt content, $\mathrm{pH}$ and lactic acid content, textural parameters, and meltability, within each type of cheese was found. Therefore, it should be advisable to improve the standardization of milk and cheese-making processes in order to produce more uniform cheeses.

Most of the Mexican cheeses considered in the present study are unripened or shortly ripened and are melted before serving. Longer ripening periods could be suggested in order to increase their meltability. Further research on the effect of ripening on meltability and textural parameters of Mexican cheeses should be carried out. Moreover, the changes in the cheese properties due to storage time also need further study.

\section{Acknowledgements}

The authors are grateful to the Instrumental Laboratory of the University of Leon, Spain, in which the mineral content of cheese was determined. The laboratory work was financially supported by the Mexican Governmental PROMEP-SEP Programme.

\section{REFERENCES}

[1] J. Hnosko, S. Clark and D. Van Hekken, "Latin American cheeses,” In: S. Clark, M. Costello, M. A. Drake and F. Bodyfelt, Eds., The Sensory Evaluation of Dairy Products, Springer-Verlag, New York, 2009, pp. 489-504.

[2] J. A. Saltijeral, V. B. Álvarez and B. García, "Presence of Listeria monocytogenes in Mexican Cheeses,” Journal of Food Safety, Vol. 19, No. 4, 1999, pp. 241-247. http://dx.doi.org/10.1111/j.1745-4565.1999.tb00249.x 
[3] C. Solano-López and H. Hernández-Sánchez, "Behaviour of Listeria monocytogenes during the Manufacture and Ripening of Manchego and Chihuahua Mexican Cheeses," International Journal of Food Microbiology, Vol. 62, No. 1-2, 2000, pp. 149-153. http://dx.doi.org/10.1016/S0168-1605(00)00403-7

[4] C. Alvarado, B. E. García-Almendarez, S. E. Martín and C. Regalado, “Anti-Listeria monocytogenes BacteriocinLike Inhibitory Substances from Enterococcus faecium UQ31 Isolated from Artisan Mexican-Style Cheese,” Current Microbiology, Vol. 51, No. 2, 2005, pp. 110-115. http://dx.doi.org/10.1007/s00284-005-4549-y

[5] A. L. Bricker, D. L. Van Hekken, V. M. Guerrero and A. A. Gardea, "Microflora Isolated from Mexican Mennonite-Style Cheeses," Food Protection Trends, Vol. 25, No. 8, 2005, pp. 637-640.

[6] M. J. Torres-Llánez, B. Vallejo-Córdoba, M. E. DíazCinco, M. A. Mazorra-Manzano and A. F. GonzálezCórdoba, "Characterization of the Natural Microflora of Artisanal Mexican Fresco Cheese,” Food Control, Vol. 17, No. 9, 2006, pp. 683-690. http://dx.doi.org/10.1016/j.foodcont.2005.04.004

[7] I. Caro, J. Mateo, M. H. Sandoval, S. Soto, M. R. GarcíaArmesto and J. M. Castro, "Characterization of Oaxaca Raw Milk Cheese Microbiota with Particular Interest in Lactobacillus Strains,” Journal of Dairy Science, Vol. 96, No. 6, 2013, pp. 3461-3470. http://dx.doi.org/10.3168/jds.2012-6103

[8] L. A. Alba, C. de Staff, C. R. L. Richter and C. V. Dill, "Mexican Asadero Cheese: A Survey of Its Composition," Journal of Dairy Science, Vol. 73, No. S1, 1990, p. 269.

[9] M. E. Díaz-Cinco, O. Fraijo, P. Grajeda, J. Lozano-Taylor and E. G. de Mejía, "Microbial and Chemical Analysis of Chihuahua Cheese and Relationship to Histamine and Tyramine,” Journal of Food Science, Vol. 57, No. 2, 1992, pp. 355-356,365. http://dx.doi.org/10.1111/j.1365-2621.1992.tb05493.x

[10] D. L. Van Hekken, M. H. Tunick, P. M. Tomasula, R. Molina-Corral and A. A. Gardea, "Mexican Queso Chihuahua: Rheology of Fresh Cheese," International Journal of Dairy Technology, Vol. 60, No. 1, 2007, pp. 5-12. http://dx.doi.org/10.1111/j.1471-0307.2007.00291.x

[11] M. H. Tunick, D. L. Van Hekken, F. J. Molina-Corral, P. M. Tomasula, J. Call, J. Luchansky and A. A. Gardea, "Queso Chihuahua: Manufacturing Procedures, Composition, Protein Profiles, and Microbiology,” International Journal of Dairy Technology, Vol. 61, No. 1, 2008, pp. 62-69. http://dx.doi.org/10.1111/j.1471-0307.2008.00359.x

[12] E. M. De Oca-Flores, O. A. Castelán-Ortega, J. G. Estrada-Flores and A. Espinoza-Ortega, "Oaxaca Cheese: Manufacture Process and Physicochemical Characteristics,” International Journal of Dairy Technology, Vol. 62, No. 4, 2009, pp. 535-540. http://dx.doi.org/10.1111/j.1471-0307.2009.00533.x

[13] M. H. Tunick and D. L. Van Hekken, "Rheology and Texture of Commercial Queso Fresco Cheeses Made from Raw and Pasteurized Milk,” Journal of Food Quality, Vol. 33, No. S1, 2010, pp. 204-215. http://dx.doi.org/10.1111/j.1745-4557.2010.00331.x

[14] J. A. Guerra-Martínez, J. G. Montejano and S. T. Martíndel-Campo, "Evaluation of Proteolytic and Physicochemical Changes during Storage of Fresh Panela Cheese from Queretaro, Mexico and Its Impact in Texture,” CyTA Journal of Food, Vol. 10, No. 4, 2012, pp. 296-305.

[15] A. D. Solís-Méndez, J. G. Estrada-Flores and O. Castelán-Ortega, "A Study on the Texture Diversity of the Artisan Ranchero Cheese from Central Mexico,” International Journal of Dairy Technology, Vol. 66, No. 1, 2013, pp. 37-44.

http://dx.doi.org/10.1111/j.1471-0307.2012.00881.x

[16] J. M. Bruna, E. M. Hierro, L. De la Hoz, D. S. Mottram, M. Fernández and J. A. Ordoñez, "Changes in Selected Biochemical and Sensory Parameters as Affected by the Superficial Inoculation of Penicillium camemberti on Dry Fermented Sausages," International Journal of Food Microbiology, Vol. 85, No. 1-2, 2003, pp. 111-125. http://dx.doi.org/10.1016/S0168-1605(02)00505-6

[17] Association of Official Analytical Chemists (AOAC), "Official Methods of Analysis of the Association of Official Analytical Chemists,” 16th edition, 5th Revision. P. Cunniff, Ed., Chapter 33, AOAC International, Gaithersburg, 1999, pp. 58-63.

[18] D. González de Llano, A. Rodríguez and P. Cuesta, "Effect of Lactic Starter Cultures on the Organic Acid Composition of Milk and Cheese during Ripening-Analysis by HPLC,” Journal of Applied Bacteriology, Vol. 80, No. 5, 1996, pp. 570-576.

http://dx.doi.org/10.1111/j.1365-2672.1996.tb03259.x

[19] H. Rosen, "A Modified Ninhydrin Colorimetric Analysis for Amino Acids," Archives of Biochemistry and Biophysics, Vol. 67, No. 1, 1957, pp. 10-15. http://dx.doi.org/10.1016/0003-9861(57)90241-2

[20] M. T. Osorio, J. M. Zumalacárregui, B. Bermejo, A. Lozano, A. Figueira and J. Mateo, “Effect of Ewe's Milk versus Milk-Replacer Rearing on Mineral Composition of Suckling Lamb Meat and Liver," Small Ruminant Research, Vol. 68, No. 3, 2006, pp. 296-302. http://dx.doi.org/10.1016/j.smallrumres.2005.11.010

[21] A. I. Carrapiso, M. L. Timón, M. J. Petrón, J. F. Tejeda and C. García, "In Situ Transesterification of Fatty Acids from Iberian Pig Subcutaneous Adipose Tissue," Meat Science, Vol. 56, No. 2, 2000, pp. 159-164. http://dx.doi.org/10.1016/S0309-1740(00)00035-8

[22] M. T. Osorio, J. M. Zumalacárregui, A. Figueira and J. Mateo, "Physicochemical Properties of Perirenal and Omental Fat form Suckling Lamb Carcasses Evaluated According to the Type of Milk Source," Small Ruminant Research, Vol. 72, No. 2-3, 2007, pp. 111-118. http://dx.doi.org/10.1016/j.smallrumres.2006.09.001

[23] T. Van Villet, "Terminology to Be Used in Cheese Rheology," In: Rheological and Fracture Properties of Cheeses, IDF Standard 268, International Dairy Federation, Brussels, 1991, pp. 5-15.

[24] T. P. Guinee, E. O. Mulholland, C. Mullins, M. O. Corcoran, J. F. Connolly, T. Beresford, R. Mehra, B. J. O’Brien, J. J. Murphy, G. Stakelum and D. Harrington, "Effect of Altering the Daily Herbage Allowance to Cows 
in Mid Lactation on the Composition, Ripening and Functionality of Low-Moisture, Part-Skim Mozzarella Cheese," Journal of Dairy Research, Vol. 65, No. 1, 1998, pp. 2330. http://dx.doi.org/10.1017/S0022029997002665

[25] A. Retiveau, D. H. Chambers and E. Esteve, "Developing a Lexicon for the Flavor Description of French Cheeses," Food Quality and Preference, Vol. 16, No. 6, 2005, pp. 517-527. http://dx.doi.org/10.1016/j.foodqual.2004.11.001

[26] E. A. Foegeding and M. A. Drake, "Invited Review: Sensory and Mechanical Properties of Cheese Texture,” Journal of Dairy Science, Vol. 90, No. 4, 2007, pp. 1611-1624. http://dx.doi.org/10.3168/jds.2006-703

[27] A. Marcos, R. Millán, M. A. Esteban, M. Alcalá and J. Fernández-Salguero, "Chemical Compositions and Water Activity of Spanish Cheeses," Journal of Dairy Science, Vol. 66, No. 12, 1983, pp. 2488-2493. http://dx.doi.org/10.3168/jds.S0022-0302(83)82116-X

[28] R. Karoui, E. Dufour, R. Schoonheydt and J. De Baerdemaeker, "Characterisation of Soft Cheese by Front Face Fluorescence Spectroscopy Coupled with Chemometric Tools: Effect of the Manufacturing Process and Sampling Zone,” Food Chemistry, Vol. 100, No. 2, 2006, pp. 632642. http://dx.doi.org/10.1016/j.foodchem.2005.09.082

[29] C. H. Hwang and S. Gunasekaran, "Measuring Crumbliness of Some Commercial Queso Fresco-Type Latin American Cheeses,” Milchwissenschaft, Vol. 56, No. 8, 2001, pp. 446-450.

[30] C. R. Cunha, W. H. Viotto and L. A. Viotto, "Use of Low Concentration Factor Ultrafiltration Retentates in Reduced Fat 'Minas Frescal' Cheese Manufacture: Effect on Composition, Proteolysis, Viscoelastic Properties and Sensory Acceptance,” International Dairy Journal, Vol. 16, No. 3, 2006, pp. 215-224. http://dx.doi.org/10.1016/j.idairyj.2005.03.004

[31] A. J. Pastorino, C. L. Hansen and D. J. McMahon, "Effect of $\mathrm{pH}$ on the Chemical Composition and Structure-Function Relationships of Cheddar Cheese,” Journal of Dairy Science, Vol. 86, No. 9, 2003, pp. 2751-2760. http://dx.doi.org/10.3168/jds.S0022-0302(03)73871-5

[32] United State Department of Agriculture (USDA), "National Nutrient Database for Standard Reference," Release 26, Agricultural Research Service, Nutrient Data Laboratory, 2011.

[33] P. S. Kindstedt, "Effect of Manufacturing Factors, Composition, and Proteolysis on the Functional Characteristics of Mozzarella Cheese,” Critical Reviews in Food Science and Nutrition, Vol. 33, No. 2, 1993, pp. 167-187. http://dx.doi.org/10.1080/10408399309527618

[34] S. Menéndez, R. Godínez, I. A. Centeno and J. L. Rodríguez-Otero, "Microbiological, Chemical and Biochemical Characteristics of 'Tetilla' Raw Cows-Milk Cheese," Food Microbiology, Vol. 18, No. 2, 2001, pp. 151-158. http://dx.doi.org/10.1006/fmic.2000.0385

[35] B. Martin, I. Verdier-Metz, S. Buchin, C. Hurtaud and J. B. Coulon, "How Do the Nature of Forages and Pasture Diversity Influence the Sensory Quality of Dairy Livestock Products," Animal Science, Vol. 81, No. 2, 2005, pp. 205-212. http://dx.doi.org/10.1079/ASC50800205
[36] P. Secchiari, M. Antongiovanni, M. Mele, A. Serra, A. Buccioni, G. Ferruzzi, F. Paoletti and F. Petacchi, "Effect of Kind of Dietary Fat on the Quality of Milk Fat from Italian Friesian Cows," Livestock Production Science, Vol. 83, No. 1, 2003, pp. 43-52. http://dx.doi.org/10.1016/S0301-6226(03)00043-5

[37] S. Carpino, J. Home, C. Melilli, G. Licitra, D. M. Barbano and P. J. Van Soest, "Contribution of Naïve Pasture to the Sensory Properties of Ragusano Cheese,” Journal of Dairy Science, Vol. 87, No. 2, 2004, pp. 308-315. http://dx.doi.org/10.3168/jds.S0022-0302(04)73169-0

[38] M. A. Rudan, D. M. Barbano, M. R. Guo and P. S. Kindstedt, "Effect of the Modification of Fat Particle Size by Homogenization on Composition, Proteolysis, Functionality, and Appearance of Reduced Fat Mozzarella Cheese,” Journal of Dairy Science, Vol. 81, No. 8, 1998, pp. 2065-2076.

http://dx.doi.org/10.3168/jds.S0022-0302(98)75781-9

[39] T. Bergann and M. Schick, “Abhaengigkeit der L*a*b*Farbwerte vom Fettgehalt und der Waermebehandlungsart," DMZ, Lebensmittelindustrie und Milchwirtschaft, Vol. 119, No. 9, 1998, pp. 464-468.

[40] M. Petersen, L. Wiking and H. Stapelfeldt, "Light Sensitivity of Two Colorants for Cheddar Cheese. Quantum Yields for Photodegradation in an Aqueous Model System in Relation to Light Stability of Cheese in Illuminated Display,” Journal of Dairy Research, Vol. 66, No. 4, 1999, pp. 599-607. http://dx.doi.org/10.1017/S0022029999003866

[41] J. J. Sheehan, T. Huppertz, M. G. Hayes, A. L. Kelly, T. P. Beresford and T. P. Guinee, "High Pressure Treatment of Reduced-Fat Mozzarella Cheese: Effects on Functional and Rheological Properties," Innovative Food Science and Emerging Technologies, Vol. 6, No. 1, 2005, pp. 7381. http://dx.doi.org/10.1016/j.ifset.2004.10.003

[42] D. Kristensen, V. Orlien, G. Mortensen, P. Brockho and L. H. Skibsted, "Light-Induced Oxidation in Sliced Havarti Cheese Packaged in Modified Atmosphere,” International Dairy Journal, Vol. 10, No. 1-2, 2000, pp. 95103. http://dx.doi.org/10.1016/S0958-6946(00)00028-5

[43] M. Juric, G. Bertelsen, G. Mortensen and M. A. Petersen, "Light-Induced Colour and Aroma Changes in Sliced, Modified Atmosphere Packaged Semi-Hard Cheeses," International Dairy Journal, Vol. 13, No. 2-3, 2003, pp. 239-249.

http://dx.doi.org/10.1016/S0958-6946(02)00156-5

[44] J. J. Yun, D. M. Barbano, P. S. Kindstedt and K. L. Larose, "Mozzarella Cheese: Impact of Whey $\mathrm{pH}$ at Draining on Chemical Composition, Proteolysis, and Functional Properties,” Journal of Dairy Science, Vol. 78, No. 1, 1995, pp. 1-7. http://dx.doi.org/10.3168/jds.S0022-0302(95)76609-7

[45] J. Y. Imm, E. J. Oh, K. S. Han, S. Oh, Y. W. Park and S. H. Kim, "Functionality and Physico-Chemical Characteristics of Bovine and Caprine Mozzarella Cheeses during Refrigerated Storage,” Journal of Dairy Science, Vol. 86, No. 9, 2003, pp. 2790-2798. http://dx.doi.org/10.3168/jds.S0022-0302(03)73876-4

[46] T. P. Guinee, D. Harrington, M. O. Corcoran, E. O. Mul- 
holland and C. Mullins, "The Compositional and Functional Properties of Commercial Mozzarella, Cheddar and Analogue Cheeses,” International Journal of Dairy Tech- nology, Vol. 53, No. 2, 2000, pp. 51-56.

http://dx.doi.org/10.1111/j.1471-0307.2000.tb02658.x 